Gut, 1980, 21, 528-532

\title{
Relationship of postprandial serum gastrin response to sex, body weight, blood group status, familial dyspepsia, duration, and age of onset of ulcer symptoms in duodenal ulcer
}

\author{
S K LAM* AND G B ONG \\ From the Combined Gastrointestinal Unit, Departments of Medicine and Surgery, \\ University of Hong Kong, Queen Mary Hospital, Hong Kong
}

SUMMARY Integrated postprandial serum gastrin levels were studied in a prospective series of 144 Chinese patients with duodenal ulcer in relation to sex, total body weight, age of onset and duration of ulcer symptoms, blood group status, and positivity for familial dyspepsia. Postprandial gastrin was unrelated to sex, total body weight, duration of symptoms, and blood group status. Patients whose onset age was in the first two decades (early onset group) had significantly higher postprandial gastrin than those with onset age in the 4th and 6th decades $(P<0.01)$. This was found to be associated with the presence in the early onset group $(n=35)$ of a high proportion of patients with positive family history of ulcer dyspepsia $(n=24)$, in whom postprandial gastrin was significantly higher than those without such history $(\mathrm{P}<0 \cdot 01)$. These results suggest that early onset patients who are positive for family history of ulcer dyspepsia segregate to form one subgroup of duodenal ulcer. They also offer a clue that familial hypergastrinaemia may be one marker for familial duodenal ulcer.

A significant proportion of patients with duodenal ulcer have a positive family history of ulcer dyspepsia. ${ }^{1-8}$ Patients with duodenal ulcer also have an excess incidence of blood group $\mathrm{O}^{8-10}$ In addition, those patients whose symptoms begin in the first two decades of life (early onset patients) have a significantly stronger family history of ulcer dypepsia than those whose symptoms begin from the fourth decade of life onwards (late onset patients). The blood group distribution of the early onset patients is the same as in the general population, whereas blood group $\mathrm{O}$ prevails in the late onset patients. ${ }^{11}$ Duodenal ulcer patients have higher gastric acid secretion than normal, and this has recently been reviewed. ${ }^{12}$ Much data have accumulated in the literature concerning the relationship of blood group and acid secretion, ${ }^{813-17}$ although this still remains controversial. ${ }^{18}$ Furthermore, it has been shown that those patients with a family history of ulcers are more prone to acid hypersecretion. ${ }^{16} 1920$ Although postprandial hypergastrinaemia

*Address for correspondence: S K Lam, Department of Medicine, University of Hong Kong, Queen Mary Hospital, Hong Kong. Received for publication 11 December 1979 is well recognised in duodenal ulcer patients, ${ }^{21}$ no data, however, exist regarding the relationship in these patients of serum gastrin to blood group, familial ulcer dyspepsia, and onset age of ulcer symptoms. This forms the basis of the present prospective study.

\section{Methods}

\section{PATIENTS}

A series of 144 patients with duodenal ulcers as shown on endoscopy were studied. These patients were all undergoing preliminary investigations before being put into either a therapeutic trial or a surgical trial on various forms of vagotomies. Patients were excluded from the study if they had obstruction due to pyloroduodenal stenosis, if they had previous gastric surgery, or if they had a concomitant medical problem-particularly cardiorespiratory, renal, or hepatic insufficiency. A detailed clinical record was obtained from each patient with particular attention to age of onset of ulcer symptoms, duration of ulcer symptoms, and family history of ulcer dyspepsia. Patients were interrogated 
about their first degree relatives regarding the presence of ulcer dyspepsia, the occurrence of ulcer complications such as bleeding, perforation or stenosis, barium or endoscopic examination reporting the occurrence of an ulcer, and previous gastric surgery. If any of these was present a family history of ulcer dyspepsia was considered to be positive.

\section{GASTRIN STUDY}

Fasting started at 20.00 hours and, on the following morning, at 09.00 hours, a slow intravenous infusion of sodium chloride solution $(150 \mathrm{mM})$ was begun. After the patient had rested for 15 minutes the first blood sample was taken ( -15 minutes) and 15 minutes later (zero time) another sample was taken, after which the patient ate a standardised meal consisting of $50 \mathrm{~g}$ protein, $40 \mathrm{~g}$ carbohydrate, and $40 \mathrm{~g}$ fat in the form of milk drink (60 g Sustagen in $60 \mathrm{ml}$ milk) and Chinese style rice congee $(130 \mathrm{~g}$ minced beef in $240 \mathrm{ml}$ plain congee with $5 \mathrm{ml}$ cooking oil). Additional blood samples were taken at $15,30,45,60,90$ and 120 minutes after the start of the meal. Each sample was stored immediately at $4^{\circ} \mathrm{C}$. The serum for all samples was separated by centrifugation immediately at the end of the test and stored at $-20^{\circ} \mathrm{C}$ for subsequent radioimmunoassay of gastrin.

\section{SERUM GASTRIN}

Gastrin estimations were by radioimmunoassay ${ }^{22}$ and were performed in duplicate. Sensitivity was below $2.5 \mathrm{pmol} / 1$ of serum. Within assay and between assay coefficients of variation were $6.2 \%$ and $13.7 \%$ respectively. The antiserum reacted equally with G17 and G34.

The integrated gastrin response after the standard meal $(\Sigma G)$ of each subject was derived by computing the total area under the response curve from zero to $120 \mathrm{~min}$. $\Sigma \mathrm{G}$ was used in preference to peak gastrin response in this study as the time of occurrence of the latter varied with different patients. Furthermore, $\Sigma \mathrm{G}$ has been found to have significant negative correlation with maximum acid output in normal subjects and patients with gastric ulcers. ${ }^{23}$

\section{STATISTICAL ANALYSIS}

Chi square test, Wilcoxan's rank test, and linear regression by least square were used as appropriate. Two-tailed tests were used for confidence level for comparison between groups.

\section{Results}

SEX

There were 106 males with a mean age of $41 \cdot 1 \pm$ SD 16.0 years and 38 females with a mean age of
$47 \cdot 9 \pm$ SD $19 \cdot 5$ years. The median $\Sigma G$ of the males, 7.4 (range 1.0 to 22.1 ) $\mathrm{nmol} \mathrm{min} \mathrm{1}^{-1}$, was not statistically different from that of the females, $7 \cdot 4$ (range

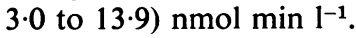

\section{BODY WEIGHT}

There was no significant correlation between total body weight $(\mathrm{kg})$ and $\Sigma \mathrm{G}(r=-0.09)$ in the 144 patients studied.

FAMILY HISTORY OF ULCER DYSPEPSIA (Table 1) Thirty patients in the whole series were positive for familial ulcer dyspepsia and their $\Sigma G$ was statistically higher than that of the remaining 114 patients who were not. Twenty-four of the 30 patients had an onset age of ulcer symptoms in the first two decades of life (early onset patients) and their $\Sigma G$ was also significantly higher than that of the 114 patients as well as that of the 11 early onset patients with negative family history.

BLOOD GROUP (Table 2)

There was no significant difference in $\Sigma G$ between individual blood groups or between blood group $\mathrm{O}$ and blood groups $\mathrm{A}, \mathrm{B}$, and $\mathrm{AB}$ taken as a group.

\section{AGE OF ONSET OF ULCER SYMPTOMS}

AND ACTUAL AGE

The distribution of the patients according to the

Table 1 Postprandial integrated serum gastrin (nmol min $\mathrm{l}^{-1}$ ) in patients with positive and negative family history of ulcer dyspepsia

\begin{tabular}{|c|c|c|c|}
\hline & \multicolumn{2}{|l|}{ Familial dyspepsia } & \multirow[t]{2}{*}{$\mathbf{P}$} \\
\hline & $+v e$ & $-v e$ & \\
\hline $\begin{array}{l}\text { Total } \\
\text { n } \\
\text { Early onset } \\
\text { n } \\
\text { Late onset } \\
\text { n }\end{array}$ & $\begin{array}{l}9.4(3.7 \text { to } 22.2) \\
30 \\
9.9(4.2 \text { to } 22 \cdot 1)^{\mathrm{a}} \\
24 \\
7.8(2.6 \text { to } 22 \cdot 2)^{\mathrm{c}} \\
6\end{array}$ & $\begin{array}{l}7 \cdot 3(1.0 \text { to } 16 \cdot 4)^{b} \\
114 \\
7 \cdot 1(1.0 \text { to } 16.4) \\
11 \\
7 \cdot 2(2.2 \text { to } 15.0) \\
103\end{array}$ & $\begin{array}{l}<0.01 \\
(T x=2616.5) \\
<0.03 \\
(T x=498) \\
\text { NS }\end{array}$ \\
\hline
\end{tabular}

ab: $P<0.01(T x=2155.5)$, ac: NS.

Median and range are shown. In this and Table 3, Tx= rank sum for group with larger median. NS= not significant.

Table 2 Postprandial integrated serum gastrin ( $n$ mol min $\mathrm{l}^{-1}$ ) in relation to blood group in 144 patients with duodenal ulcer

\begin{tabular}{|c|c|c|c|c|c|}
\hline & \multicolumn{5}{|c|}{ Blood group } \\
\hline & $o$ & $A$ & $B$ & $A B$ & $\begin{array}{l}\text { Non- } O \\
(A, B, A B)\end{array}$ \\
\hline $\begin{array}{l}\text { Number } \\
\text { Median } \\
\text { Range }\end{array}$ & $\begin{array}{l}80 \\
7 \cdot 2 \\
1.0 \text { to } 22 \cdot 2\end{array}$ & $\begin{array}{l}28 \\
7 \cdot 9 \\
3 \cdot 2 \text { to } 19 \cdot 6\end{array}$ & $\begin{array}{l}32 \\
8 \cdot 6 \\
3 \cdot 0 \text { to } 22 \cdot 1\end{array}$ & $\begin{array}{l}4 \\
7 \cdot 4 \\
4 \cdot 3 \text { to } 14 \cdot 1\end{array}$ & $\begin{array}{l}64 \\
8 \cdot 3 \\
3 \cdot 0 \text { to } 22 \cdot 1\end{array}$ \\
\hline
\end{tabular}

No significant differences between group $\mathbf{O}$ and group $\mathbf{A}$ or $\mathbf{B}$, or between group $\mathrm{O}$ and non-O. 
Table 3 Distribution of patients according to onset age of ulcer symptoms and age at presentation, and the relationship of these to postprandial integrated serum gastrin levels (nmol min $^{-1}$ )

\begin{tabular}{|c|c|c|c|c|c|c|}
\hline & \multicolumn{6}{|c|}{ Age at onset (yr) } \\
\hline & $11-20$ & $21-30$ & $31-40$ & $41-50$ & $51-60$ & $>60$ \\
\hline $\begin{array}{l}\text { Onset age (yr) } \\
\text { n } \\
\text { Median } \\
\text { Range }\end{array}$ & $\begin{array}{l}34 \\
9 \cdot 4^{\mathrm{a}} \\
4 \cdot 2 \text { to } 22 \cdot 1\end{array}$ & $\begin{array}{l}23 \\
7 \cdot 4^{\mathrm{b}} \\
1.0 \text { to } 13.3\end{array}$ & $\begin{array}{l}26 \\
6 \cdot 2 \mathrm{c} \\
2 \cdot 2 \text { to } 14 \cdot 6\end{array}$ & $\begin{array}{l}33 \\
7 \cdot 1^{d} \\
2 \cdot 6 \text { to } 19 \cdot 6\end{array}$ & $\begin{array}{l}13 \\
6 \cdot 5 \mathrm{e} \\
3 \cdot 4 \text { to } 9 \cdot 7\end{array}$ & $\begin{array}{l}14 \\
9 \cdot 1^{2} \\
3 \cdot 2 \text { to } 22 \cdot 2\end{array}$ \\
\hline $\begin{array}{l}\text { Age (yr) } \\
\text { n } \\
\text { Median } \\
\text { Range }\end{array}$ & $\begin{array}{l}19 \\
8 \cdot 2 \\
4 \cdot 2 \text { to } 20 \cdot 9\end{array}$ & $\begin{array}{l}22 \\
7 \cdot 9 \\
3 \cdot 3 \text { to } 22 \cdot 1\end{array}$ & $\begin{array}{l}25 \\
7 \cdot 1 \\
2 \cdot 7 \text { to } 15 \cdot 0\end{array}$ & $\begin{array}{l}31 \\
7 \cdot 2 \\
1.0 \text { to } 16.4\end{array}$ & $\begin{array}{l}26 \\
6 \cdot 7 \\
3.0 \text { to } 13.9\end{array}$ & $\begin{array}{l}21 \\
8 \cdot 1 \\
2 \cdot 3 \text { to } 22 \cdot 2\end{array}$ \\
\hline
\end{tabular}

No significant differences between groups for actual age.

ac: $P<0.01(T x=1186)$, ae: $P<0.01(T x=907)$. ab, ad, af: not significant.

onset age of ulcer symptoms is shown in Table 3. Two significant peaks were observed at the second and fifth decades $\left(\chi_{5}^{2}=18.99, \mathrm{P}<0.005\right)$. There was an obvious trend for patients under 20 years and those over 60 years of age to have higher $\Sigma G$ than the rest. The apparent differences became much weaker when the actual age instead of onset age was used. As the present data and previous work ${ }^{11}$ indicate that patients with age of onset of symptoms below 20 years stand out as a group, the $\Sigma G$ of this group was compared with those of the groups having a more advanced age of onset. As this would involve multiple comparisons, only those results with significance at $1 \%$ level or less were considered significant for the purpose of this study. It was found that the $\Sigma G$ of the early onset patients was significantly higher than that of the patients whose onset age was in the fourth and sixth decades. It is to be noted that, because the patients involved in this study were drawn from patients undergoing medical and surgical trials, they were mainly adult patients and there was only one patient in this series whose age of onset was in the first decade. He was therefore excluded from analysis as far as age of onset was concerned.

\section{DURATION OF SYMPTOMS}

There was no significant relationship between duration of ulcer symptoms and $\Sigma G$ (Table 4).

Table 4 Postprandial integrated serum gastrin ( $\mathrm{nmol}$ min $\mathrm{l}^{-1}$ ) in relation to duration of symptoms in years

\begin{tabular}{lllll}
\hline \multicolumn{5}{c}{ Duration of symptoms $(y r)$} \\
\cline { 2 - 5 } & 1 & $1-5$ & $6-10$ & 10 \\
\hline n & 27 & 51 & 45 & 21 \\
Median & $7 \cdot 1$ & $7 \cdot 9$ & $7 \cdot 9$ & $8 \cdot 1$ \\
Range & $(2 \cdot 2$ to $15 \cdot 0)$ & $(1 \cdot 0$ to $22 \cdot 1)$ & $(2 \cdot 7$ to $19 \cdot 6)$ & $(2 \cdot 7$ to $21 \cdot 2)$ \\
\hline
\end{tabular}

No significant difference between groups.
FASTING SERUM GASTRIN

Fasting serum gastrin levels were also examined with respect to onset age and positivity for family history of ulcer dyspepsia. No significant difference was observed between the early and late onset groups, nor between family history positive or family history negative groups (Table 5). When the fasting levels were examined with respect to the various decades of onset age (Table 6), patients in the seventh decade had a significantly $(P<0.01)$ higher fasting gastrin level than those in the third decade. When the fasting levels were examined with respect to actual age at presentation (Table 6), patients in the seventh decade had a significantly higher fasting level than those in the fourth and fifth decades. As before, only P values of less than 0.01 were considered as significant.

\section{Discussion}

We observed that postprandial serum gastrin was significantly higher in the 30 patients who gave a positive family history of ulcer dyspepsia than those without such history. It has been shown that patients with a family history of ulcers are more prone to acid hypersecretion..$^{19} 20$ It has also been shown

Table 5 Fasting serum gastrin levels (pmol $l^{-1}$ ) in patients with early and late onset age, and with positive and negative family history of ulcer dyspepsia

\begin{tabular}{llll}
\hline & \multicolumn{2}{l}{ Familial dyspepsia } \\
\cline { 2 - 4 } & $+v e$ & $-v e$ & Total \\
\hline Early onset & $35(7$ to 68$)$ & $25(5$ to 54$)$ & $33(5$ to 68$)$ \\
n & 24 & 11 & 35 \\
Late onset & $36(3$ to 66$)$ & $31(0$ to 108$)$ & $31(0$ to 108$)$ \\
n & 6 & 103 & 109 \\
Total & $36(3$ to 68$)$ & $31(0$ to 108$)$ & \\
n & 30 & 114 & \\
\hline
\end{tabular}

No significant difference between groups. Median and range are shown. 
Table 6 Fasting serum gastrin levels (pmol $\left.\mathrm{l}^{-1}\right)$ at various decades of onset age and age at presentation

\begin{tabular}{lllllll}
\hline \multicolumn{1}{l}{ Decade of onset } & & & \\
\cline { 2 - 7 } & $11-20$ & $21-30$ & $31-40$ & $41-50$ & $51-60$ & $>60$ \\
\hline Onset age & $32(7$ to 68$)$ & $28(3 \text { to } 50)^{\mathrm{a}}$ & $26(11$ to 51$)$ & $34(0$ to 108$)$ & $29(12$ to 52$)$ & $42(18 \text { to } 90)^{\mathrm{b}}$ \\
Age (yr) & $1(7$ to 68$)$ & $33(10$ to 65$)$ & $25(3 \text { to } 52)^{\mathrm{c}}$ & $26(0 \text { to } 49)^{\mathrm{d}}$ & $35(12$ to 58$)$ & $45(12 \text { to } 108)^{\mathrm{e}}$ \\
\hline
\end{tabular}

Median and range are shown.

$\mathrm{ab}: \mathrm{P}<0.01(\mathrm{Tx}=383)$. ce: $\mathrm{P}<0.01(\mathrm{Tx}=614)$, de: $\mathrm{P}<0.01(\mathrm{Tx}=711)$. Comparisons between other groups not significant.

that hyperpepsinogenaemia I can be transmitted by autosomal dominance in duodenal ulcer. ${ }^{24}$ Our findings suggest that postprandial hypergastrinaemia may be another marker of familial ulcers, and family studies of postprandial hypergastrinaemia among duodenal ulcer patients are clearly required.

The present prospective study confirms a previous retrospective study ${ }^{11}$ in showing that in the Chinese community in Hong Kong, patients with duodenal ulcer fall into two groups with respect to the age of onset of ulcer symptoms, one (early onset group) having a peak frequency in the first two decades and the other (late onset group) having its peak at about the fourth and fifth decades (fourth in the previous study, fifth in the present). Analysis of the distribution of the postprandial gastrin levels with respect to the onset age reveals a clear trend for patients with early onset age and patients with onset of symptoms at the seventh decade onwards to have higher postprandial serum gastrin than the rest of the patients. This trend does not stand out when the actual age of the patients is used instead of the onset age. Comparison of the early onset group with groups having a more advanced onset age reveals that the early onset patients have significantly higher postprandial serum gastrin than those with onset age at the fourth and sixth decades. This difference is not related to the duration of the disease, as duration does not increase postprandial serum gastrin (Table 4), unlike its effect on acid secretion. ${ }^{25}{ }^{26}$ The present findings suggest that early onset patients have higher postprandial serum gastrin than the late onset patients, in whom, however, postprandial serum gastrin appears to rise again from the seventh decade onwards. Such a higher level in the later decades of life is even more pronounced when fasting serum gastrin levels are examined (Table 6). The rise in gastrin in later life may be explained by the occurrence of atrophic gastritis known to be associated with aging.

Workers who have examined the frequency of familial ulcer dyspepsia in adults, ${ }^{81120}$ in adolescents, ${ }^{27}$ and in children ${ }^{28-33}$ with duodenal ulcer have been impressed by the increased frequency with which this occurs in younger patients. In the present study, 24 of the 35 early onset patients are positive for familial ulcer dyspepsia. It appears from Table 1 that it is this subgroup of patients which accounts for the increased postprandial serum gastrin in the early onset subjects compared with the late onset group. In the late onset group, those who are positive for familial ulcer dyspepsia appear to have similar postprandial serum gastrin to those who are not. The number of patients with positive family history in the late group is however too small in the present study to allow any meaningful statistical evaluation. The present study therefore does not allow us to draw any firm conclusion about whether the effect on gastrin level in the early onset group is through the earliness in onset, through the positive family history -which is strongly associated with earliness in onset-or through both. The available data seem to indicate that both are required.

Much evidence has now accumulated to support the concept that duodenal ulcer is a heterogeneous group of disorders. ${ }^{1134-36}$ The present study strongly suggests that the early onset patients who are positive for family history of ulcer dyspepsia segregate to form one subgroup.

We are most grateful to Dr Morton Grossman for reviewing the paper and for his invaluable criticisms. We wish to thank our colleagues of the Departments of Medicine and Surgery for their support in this study, Dr Janet Elashoff for her statistical advice, Mr Patrick Wong for his technical assistance in the gastrin assay, and Ms Anita Boesman and Ms Melanie Lee for secretarial help. This study is supported in part by the Medical Faculty Research Grant (No. 311/030/8010/12), University of Hong Kong.

\section{References}

${ }^{1}$ Doll R, Buch J. Hereditary factors in peptic ulcer. Ann Eugenics 1950; 15: 135-46.

${ }^{2}$ Grossman MI and Ivy AC. Heredity and peptic ulcer. Gastroenterology 1950; 16: 793-4.

${ }^{3}$ Kuenssberg EV. Are duodenal ulcer and chronic bronchitis family diseases? Proc Roy Soc Med 1962; 55: 299-302.

${ }^{4}$ Sklaroff SA. Use of National Health Service general 
practice records in epidemiological inquiries: duodenal ulcer-a test case. Br J Prevent Soc Med 1963; 17: 177-84.

${ }^{5}$ Gillies MA, Skyring A. Gastric and duodenal ulcer. The association between aspirin ingestion, smoking, and family history of ulcer. Med J Australia 1969; 2: 280-5. 'Jirásek V. Hereditary factors in the aetiology of peptic ulcer. Acta Univ Carol [Med] (Praha) 1971; 17: 383-455. ${ }^{7}$ Kubičková Z, Veselý KT. The value of investigations of the incidence of peptic ulcer in the families of patients with duodenal ulcer. J Med Genet 1972; 9: 38-42.

${ }^{8}$ Lam SK, Sircus W. Studies on duodenal ulcer-I. The clinical evidence for the existence of two populations. Quart J Med 1975: 44: 369-87.

${ }^{9}$ Aird I, Bentall HH, Mehigan JA, Roberts JAF. The blood groups in relation to peptic ulceration and carcinoma of colon, rectum, breast and bronchus. Br Med J 1954; 2 : 315-21.

${ }^{10}$ Langman MJS, Doll R. ABO blood group and secretor status in relation to clinical characteristics of peptic ulcers. Gut 1965; 6: 270-3.

${ }^{11}$ Lam SK, Ong GB. Duodenal ulcers: early and late onset. Gut 1976; 17: 169-79.

${ }^{12}$ Baron JH. The clinical application of gastric secretion measurements. Clin Gastroenterol 1973; 2: 293-314.

${ }^{13}$ Brown DAP, Melrose AG, Wallace J. The blood groups in peptic ulceration. $\mathrm{Br} \mathrm{Med} J$ 1956; 2 : 135-8.

${ }^{14}$ Buckwalter JA, Wohlwend EB, Colter DC, Tidrick RT, Knowler LA. Peptic ulceration and ABO blood groups. JAMA 1956; 162: 1215-20.

${ }^{15}$ Ventzke LE, Grossman MI. Response of patients with duodenal ulcer to augmented histamine tests as related to blood groups and to secretor status Gastroenterology 1962; 42: 292-4.

${ }^{16}$ Fodor $\mathrm{O}$, Vestea $\mathrm{S}$, Urcan $\mathrm{S}$, et al. Hydrochloric acid secretion capacity of the stomach as an inherited factor in the pathogenesis of duodenal ulcer. Am J Dig Dis 1968; 13: 260-5.

${ }^{17}$ Veselý KT, Kubíčková Z, Dvořáková M. Clinical data and characteristics differentiating types of peptic ulcer. Gut 1968; 9: 57-68.

${ }^{18}$ Prescott RJ, Sircus W, Lai CL, Lam SK. Failure to confirm evidence for existence of two populations in duodenal ulcer. $\mathrm{Br}$ Med J 1976; 2: 677.

${ }^{19}$ Lander FPL, MacClagan NF. One hundr zd histamine test-meals on normal students. Lancet 1934; 2: 1210-3.

${ }^{20}$ Artemiev EN, Vildt MO, Potiakina NN, Musnitskaya, EN. The importance of the hereditary factor in the pathogenesis of peptic ulcer. (Russian) Sov Med 1970; 33 (4): 54-8.
${ }^{21}$ Walsh JH, Grossman MI. Gastrin (Part 2). $N$ Engl J Med 1975; 292 : 1377-84.

${ }^{22}$ Lam, SK, Lai, CL. Inhibition of sulpiride on the cephalic phase of gastric acid and gastrin secretion in duodenal ulcer patients. Scand J Gastroenterol 1976; 11: $27-31$

${ }^{23}$ Lam SK, Lai CL. Gastric ulcers with and without associated duodenal ulcer have different pathophysiology. Clin Sci Mol Med 1978; 55: 97-102.

${ }^{24}$ Rotter JI, Sones JQ, Samloff MI et al. Duodenal-ulcer disease associated with elevated serum pepsinogen I: an inherited autosomal dominant disorder. $N$ Eng J Med 1978; 300: 63-6.

${ }^{25}$ Sircus W. Gastric secretion in peptic ulcer disease with special reference to the influence of body weight, duration of disease and stenosis. In: Semb LS, Myren J, eds. Physiology of gastric secretion. Oslo: Universitets forlaget, 1968: 581-591.

${ }^{26}$ Hobsley M, Whitfield PF, Faber RG, Parkin JV. Hypersecretion and length of history in duodenal ulceration. Lancet 1975: 2: 101-4.

${ }^{27}$ Jirásek V, Gregor O. Peptic ulcer in adolescents. Acto Univ Carol [Med] (Praha) 1971; 17: 339-82.

${ }^{28}$ Fällström SP, Reinand T. Peptic ulcer in children. Acta Paediatr (Stockholm) 1961; 50: 431-6.

${ }^{29}$ Milliken JC. Duodenal ulceration in children. Gut 1965 ; 6: $25-8$.

29a Habbick BR, Melrose AG, Grant JC. Duodenal ulcer in childhood. Arch Dis Child 1968; 43: 23-7.

${ }^{30}$ Dogan K, Oberiter V, Najam E, Dogan S, Buneta L, Rudar D, Mark B. Peculiarities of gastric and duodenal ulcer in childhood. Lijec Vjesn 1969; 91 : 1045-58

${ }^{31}$ Sultz HA, Schlesinger ER, Feldman JG, Mosher, WE. The epidemiology of peptic ulcer in childhood. $A m J$ Pub Hlth 1970; 60: 492-8.

${ }^{32}$ Robb JDA, Thomas PS, Orszulok J, Odling-Smee GW. Duodenal ulcer in children. Arch Dis Child 1972; 47: 688-96.

${ }^{33}$ Roberts DF, Jackson RH, Cowan WK. Genetics of duodenal and gastric ulcer. Clin Gastroenterol 1973; 2: 539-46.

${ }^{34}$ Lam SK. Clinical and pathophysiological studies on duodenal ulcer: evidence for the existence of two populations. MD Thesis, University of Hong Kong, 1975.

${ }^{35}$ Rotter JI, Rimoin DL. Peptic ulcer disease-a heterogeneous group of disorders? Gastroenterology 1977; 73: 604-7.

${ }^{36}$ Grossman MI. Abnormalities of acid secretion in patients with duodenal ulcer. Gastroenterology 1978; 75: 524-6. 